\title{
Peningkatan pengetahuan dan ketrampilan menyediakan makanan sehat dan hand sanitizer alami dalam menghadapi pandemic Covid19
}

\author{
Happy Elda Murdiana ${ }^{1, *}$, Nikasius Jonet Sinangjoyo², Sarah Puspita Atmaja ${ }^{3}$, \\ Lea Octavining Tyas ${ }^{4}$ \\ ${ }^{1,3,4}$ Fakultas Farmasi, Universitas Kristen Immanuel Yogyakarta \\ ${ }^{2}$ Program Studi Pariwisata, Sekolah Tinggi Pariwisata AMPTA Yogyakarta \\ Email Korespondensi : "happy@ukrimuniversity.ac.id
}

Received May 18, 2021; Revised May 28, 2021; Accepted May 31, 2021

\begin{abstract}
Abstrak
Pandemi covid 19 belum berakhir dan masih banyak masyarakat belum menerima vaksin yang di jadwalkan oleh pemerintah sehingga semua warga harus tetap waspada terhadap infeksi virus corona 19. Infeksi virus merupakan self limiting disease yang dapat sembuh sendiri jika daya tahan tubuh kita kuat. Banyak hal yang dapat meningkatkan sistem imun, salah satunya adalah asupan gizi dari bahan makanan dan cara pengolahan yang tepat. Pemenuhan gizi makro berupa sumber energi dan protein dapat diperoleh dari hewani dan nabati, sedang gizi mikro berupa vitamin dan mineral dapat diperoleh dari daging, ikan, sayur, buah yang berwarna maupun tidak. Kandungan gizi mikro yang meningkatkan imun berupa antioksidan yang banyak terkandung dalam vitamin A, B, C, E, zink, Fe dan beberapa mineral lain. Mencuci tangan dengan sabun atau hand sanitizer merupakan program pemerintah untuk mencegah penyebaran covid 19. Mahalnya hand sanitizer dan kelangkaan barang menimbulkan ide kreatif untuk memberdayakan masyarakat dalam pembuatan hand sanitizer yang murah, mudah didapat dan aman bagi semua usia. Tujuan pengabdian masyarakat ini memberi pemahaman kepada masyarakat sumber gizi peningkat sistem imun tubuh dan cara pengolahan bahan makanan yang baik tanpa merusak kandungan gizi serta meningkatkan keterampilan mengolah bahan makanan dan membuat hand sanitizer dari bahan alami ramah lingkungan yang dapat diambil dari sekitar kita. Pengabdian dapat terlaksanan dengan baik, masyarakat merasa sangat terbantu dengan penyuluhan dan pelatihan yang diberikan. Evaluasi kegiatan dilakukan dengan pendampingan atas kreatifitas masyarakat dalam mengolah makanan bergizi dan membuat handsinitizer dengan bahan alami disekitar lingkungan kita.
\end{abstract}

Kata kunci : pandemi Covid 19; gizi; hand sanitizer alami; pengetahuan; keterampilan

Abstract

The covid 19 pandemic has not ended and there are still many people who have not received the vaccine scheduled by the government so all citizens must remain vigilant against Corona 19 virus infection. Viral infection is a self-limiting disease that can heal itself if our immune system is strong. There are many things that can increase the immune system, one of which is nutritional intake from food and proper processing methods. Fulfillment of macro nutrition in the form of energy and protein sources can be obtained from animal and vegetable sources, while micronutrients in the form of vitamins and minerals can be obtained from meat, fish, vegetables, colored fruit or not. The content of micronutrients that increase immunity is in the form of antioxidants contained in vitamins $A, B, C, E$, zinc, Fe and several other minerals. Washing hands with soap or hand sanitizer is a government program to prevent the spread of the covid 19. The high cost of hand sanitizers and the scarcity of goods have led to creative ideas to empower people in making hand sanitizers that are cheap, easy to obtain and safe for all ages. The aim of this community service is to provide understanding to the community about sources of nutrition to increase the body's immune system and how to properly process food ingredients without damaging nutritional content and improve skills in processing food ingredients and making hand sanitizers from environmentally friendly natural ingredients that can be taken from around us. Community service can be carried out well, the community feels very helped by the counseling and training provided. Evaluation of activities is carried out by assisting the community's creativity in processing nutritious food and making hand sanitizers with natural ingredients around our environment.

Keywords: covid 19 pandemic; nutrition; natural hand sanitizer; knowledge; skill 


\section{PENDAHULUAN}

Infeksi covid 19 yang berasal dari China dengan atau tanpa gejala menunjukkan tingkat keparahan yang bervariasi dari ringan sampai kritis. Persentase pasien covid 19 yang membutuhkan perawatan di ICU berkisar 26-32\% dan kematian pasien yang mendapat perawatan di ICU berkisar 39\% -72\% tergantung dari penelitian dan karakteristik populasi pasien [1]. Program vaksinasi di Indonesia masih belum menjangkau semua lapisan masyarakat, sehingga kesadaran pribadi dalam pencegahan dan pembentukan herd imunity sangat dibutuhkan. Program pemerintah 5M (memakai masker, mencuci tangan, menjaga jarak, menjauhi kerumunan, membatasi mobilisasi) untuk mencegah penyebaran covid 19 dapat diimplementasikan di masyarakat secara kreatif dan murah. Pemberdayaan membuat masker kain, membuat hand sanitizer bahan alam, melakukan interaksi dan transaksi secara virtual akan mengurangi penyebaran covid19. Masyarakat, khususnya komunitas ibu ibu dasawisma sangat membutuhkan edukasi dan aksi nyata dalam melindungi keluarganya dari infeksi covid19. Infeksi virus seperti covid 19 pada umumnya merupakan self limiting disease dengan mengandalkan kekuatan pertahanan tubuh, sehingga peningkatan daya tahan tubuh untuk mencegah penularannya dapat diupayakan dengan mengonsumsi makan, minuman yang bergizi dan obat obatan yang disarankan. Sistem imun manusia berfungsi mempertahankan tubuh terhadap substansi asing disebut dengan imunogen atau antigen [2] [3]. Jika ada antigen berupa infeksi virus masuk ke tubuh manusia maka reaksi imun terhadap infeksi virus salah satunya adalah menghalangi sebelum menginfeksi sel inang oleh antibodi dengan cara : (a) menetralisasi virus sehingga virus tidak bisa menginfeksi (b) berlekatan dengan virus sehingga mudah dikenali oleh antibodi (c) ditelan dan dirusaknya virus oleh sel yang disebut fagosit. Beberapa faktor yang memengaruhi sistem imun adalah : lingkungan, makanan, usia, kondisi kesehatan, dan konsumsi obat obatan. Beberapa bahan atau senyawa yang dapat meningkatkan sistem imun tubuh adalah : vitamin $\mathrm{C}$, vitamin $\mathrm{D}$, vitamin $\mathrm{E}$, Zink, Selenium, Herbal Echinacea, propolis, empon empon, dan meniran [2] [4].

Pemenuhan gizi menjadi perhatian untuk menjaga imunitas agar terhindar dari infeksi penyakit termasuk covid 19 [5]. Pola makan sehat yaitu aman, bergizi, beragam dan berimbang (AB3) menjadi rujukan pencegahan covid 19. Makanan bergizi berarti mengandung gizi lengkap meliputi : makronutrien, mikronutrien termasuk karbohidrat, protein, lemak, vitamin, dan mineral. Protein, vitamin dan mineral (terutama zink) mempunyai kontribusi besar dalam meningkatkan daya tahan tubuh [6] [7]. Peran gizi makro terkait imunitas termasuk pemenuhan asupan pendukung energi dan protein. Jika kekurangan protein berakibat peningkatan gangguan imunitas seperti penurunan fungsi fagositosit, sekresi antibodi dan produksi sitokin. Sedangkan gizi mikro didapat dari vitamin dan mineral. Vitamin berfungsi dalam reaksi metabolik dalam tubuh dan sel, serta pertumbuhan dan pemeliharaan [8] [9].

Protein berasal dari hewan berupa telur, daging ayam, ikan laut/tawar, daging sapi, daging kerbau, sedang protein nabati adalah kacang kacangan beserta makanan olahannya yaitu tahu dan tempe. Pangan protein hewani mengandung asam amino yang lebih lengkap dan mempunyai gizi berupa protein, vitamin dan mineral yang lebih baik karena kandungan gizinya banyak dan mudah diserap tetapi mengandung kolesterol dan lemak. Lemak daging dan unggas lebih banyak mengandung lemak jenuh. Pangan protein nabati mempunyai kandungan lemak tak jenuh yang lebih banyak, mengandung isoflavon yang berfungsi sebagai antioksidan dan antikolesterol [8]. Disarankan mengkonsumsi protein 75-100g/hari untuk meningkatkan sistem imun [10]. Vitamin A terkandung dalam semua sayur berwarna seperti wortel, bayam, kangkung, labu kuning, cabe merah. Vitamin A mudah diserap terdapat pada kuning telur, mentega, hati ayam, dan minyak ikan. Vitamin B3 (niasin) secara spesifik berfungsi mengurangi kolesterol dan mengatasi masalah sendi yang banyak terdapat pada susu, telur, ikan, kacang dan daging. Vitamin B12 meningkatkan imunitas, vitamin B6 terdapat pada ayam, ikan, hati ayam, salmon, pisang, daging sapi, nasi, beras merah. Vitamin $\mathrm{C}$ sebagai antioksidan terkait meningkatkan sistem imun tubuh banyak terdapat dalam sayuran dan buah seperti jambu biji, papaya, brokoli, strawberry, lemon, jeruk, kiwi. Vitamin E atau vitamin antipenuaan/ vitamin antioksidan terdapat pada bunga matahari, minyak wijen, minyak kelapa sawit, minyak kacang kedelai, kacang tanah, minyak zaitun. Mineral Zink yang terdapat pada kerang, daging merah, kacang, susu olahan (yogurt\&keju) telur, biji bijian, kemiri, kentang penting menjaga imunitas. Kekurangan zink berdampak penurunan limfosit yang berperan dalam imunitas. Mineral $\mathrm{Fe} /$ zat besi berperan dalam memproduksi darah merah yang mengangkut $\mathrm{O} 2$ dan $\mathrm{CO} 2$ keseluruh tubuh juga berfungsi dalam pembentukan limfosit yang banyak terdapat dalam daging merah, kuning telur, kacang kacangan, bayam, hati, ikan dan tiram [8] [11] [12].

Berbagai macam sayuran dapat dimanfaatkan sebagai peningkat imun berdasarkan warnanya : (a) sayur hijau : merupakan sumber karoten untuk antioksidan, semakin hijau semakin banyak karoten, vitamin $\mathrm{C}$, asam folat dan mineral. berfungsi juga sebagai anti kanker, produksi sel darah merah dan menguatkan sel otak. contoh : daun singkong, sawi hijau, bayam, buncis, kangkung dll. (b) sayuran ungu : mengandung antioksidan 
dan vitamin yang berfungsi meningkatkan sistem imun, meningkatkan produksi sel darah merah dan putih. contoh : terong ungu, kol ungu dll. (c) sayur kuning dan oranye : mengandung vitamin dan antioksidan. contoh : wortel, labu kuning, jagung dll. (d) sayur merah : mengandung antioksidan yang melindungi pembuluh darah, vitamin A dan E. contoh : bayam merah, lobak merah. (e) sayur putih : mengandung vitamin E, kalsium, zat alicin yang dapat mengontrol kadar kolesterol, tekanan darah dan menghambat pertumbuhan kanker. contoh : bunga kol, sawi putih [13]. Daun katuk dapat meningkatkan sistem imun [14]. Dengan merujuk pemenuhan gizi tersebut, maka upaya penyediaan makanan bergizi dan tepat cara penyajiannya merupakan hal penting dalam meningkatkan imun pencegah penularan covid 19 yang pada awalnya tidak diketahui secara detail oleh ibu ibu dasawisma.

Mencuci tangan dengan sabun atau cairan antiseptik/ hand sanitizer dalam segala situasi adalah salah satu cara mencegah penyebaran covid19. Kelangkaan hand sanitizer yang menyebabkan melonjaknya harga dipasaran menjadi pemikiran kreatif pembuatan hand sanitizer berbahan herbal yang sederhana dan mudah didapat. Pembuatan hand sanitizer menggunakan alat yang sederhana dengan biaya yang sangat murah, dan bahkan bisa diberi bahan beraroma yang kita pilih dan sukai dari tumbuhan yang sekaligus membunuh kuman (antibakteri) misalnya sere wangi, daun jeruk, kulit jeruk, daun tembelekan, daun kemangi, daun kemuning, bunga kecombrang, bunga krisan dan bunga lainnya yang terdapat disekitar rumah [15]. Minyak daun sirih hijau (Piper betle Linn) diketahui mengandung kavikol yang memiliki aktifitas antibakteri [16]. Ibu ibu dasawisma sukun sudah membiasakan menanam tumbuhan bermanfaat obat di rumah masing masing berupa tanaman salam, sereh, kemangi, kemuning, telang, kelor, bermacam jeruk dll sehingga pemberdayaan pembuatan hand sanitizer berbahan herbal ini merupakan sarana memanfaatkan tanaman obat program dasawisma Sukun.

Tujuan pengabdian masyarakat ini adalah memberi wawasan kepada masyarakat khususnya ibu ibu dasawisma Sukun dalam pemilih bahan makanan untuk diolah secara tepat sebagai peningkat daya tahan tubuh dan memanfaatkan bahan alam dalam pembuatan hand sanitizer yang murah dan aman.

\section{METODE}

Metode yang digunakan dalam pelaksanaan kegiatan pemberdayaan masyarakat ini adalah penyuluhan dan pelatihan pengolahan makanan bergizi meningkatkan sistem imun tubuh dan pembuatan hand sanitizer berbahan alam yang ramah lingkungan. Berdasarkan analisa SWOT pada komunitas dasawisma Sukun dimana kodrat seorang ibu yaitu menyediakan makanan sehat bagi keluarganya, ibu mempunyai insting melindungi keluarga dan menjaga anak serta suami terhadap hal buruk diluar rumah merupakan kekuatan (Strength), sedang menurunnya pendapatan dan terbatasnya kemampuan ibu ibu dasawisma Sukun dalam mengakses info terkait usaha pencegahan covid secara mudah menjadikan kelemahan (Weakness). Aspek Peluang (opportinity) yang dimiliki adalah semua ibu dasawisma Sukun menanam tumbuhan obat berkhasiat dipekarangan rumahnya dan semua ibu memasak sendiri setiap hari untuk keluarganya, sedang ancaman (Threat) yang dihadapi adalah penyebaran covid19 yang sangat mengancam jiwa menjadi dasar pemberian edukasi tentang pemahaman bagaimana sebenarnya infeksi virus dapat sembuh sendiri jika sistem imun tubuh baik, dan bahan apa saja yang mampu meningkatkan sistem imun kemudian implementasinya berupa praktek mengolah bahan makanan yang mempunyai kandungan gizi tinggi peningkat sistem imun dan pengolahan yang benar agar tidak merusak kandungan gizinya serta pembuatan hand sanitizer untuk mencegah penyebaran covid 19 .

Alur pelaksanaan kegiatan diawali dengan observasi analisa masalah menggunakan analisa SWOT, kemudian dilakukan koordinasi dengan pengurus dasawisma Sukun untuk kemudian mengimplementasikan kegiatan pada anggota. Implementasi kegiatan berupa :

1. Paparan penyuluhan makanan peningkat imunitas tubuh.

Tahapan ini bertujuan untuk memberi wawasan kepada mitra yaitu ibu ibu dasawisma Sukun tentang sumber makanan dan cara menyediakan makanan peningkat imun tubuh yang benar dalam pengolahan sehingga tidak mengurangi kandungan gizi saat pemasakan.

2. Pelatihan pemilihan makanan sehat dan pengolahannya

Pemilihan bahan masakan sudah disediakan panitia berupa sumber gizi mikro dan makro yang dibutuhkan untuk meningkatkan imum, baik hewani maupun nabati dengan variasi warna sayur. Pengolahan bahan makanan menyesuaikan sumbernya, agar zat berkhasiat yang terkandung tidak hilang misalnya bayam, kangkung mengandung klorofil hanya butuh pemanasan sebentar, bawang akan lebih mengeluarkan zat aktif 
saat digeprek dibanding diiris, memasak ayam kampung dengan suhu konstan misalnya dengan slow cooker akan mengurangi kerusakan kandungan protein

3. Pelatihan pembuatan handsinitizer berbahan herbal

Pembuatan handsinitizer dari bahan alam ramah lingkungan dilakukan setelah selesai pelatihan pengolahan, penyajian makanan bergizi. Pembuatan hand sanitizer diawali dengan mencuci 50 gram daun sirih hingga bersih, kemudian dikeringkan dengan cara diangin-anginkan dan pastikan kering dan bersih, potong daun sirih menjadi kecil kecil kemudian dituang $50 \mathrm{~g}$ daun ke dalam panci yang berisi $200 \mathrm{ml}$ air bersih, kemudian disiapkan panci lain yang lebih besar dan isi dengan air dingin, lalu dimasukkan panci yang berisi rendaman daun sirih ke dalam panci yang lebih besar seperti ditim dengan api kecil hingga $90{ }^{\circ} \mathrm{C}$ selama 30 menit. Setelah dingin saring rendaman daun sirih, ditambah perasan air jeruk nipis sesuai selera dan air bersih secukupnya dan aduk. Tuangkan ke dalam botol spray dan hand sanitizer siap digunakan. Penyimpanan lebih baik jika dalam suhu dingin yaitu di almari pendingin [17]. Ibu ibu dasawisma Sukun dirangsang untuk berpikir inovasi dan kreasi dalam membuat hand sanitizer menyesuaikan tanaman obat yang ditanam di rumah masing masing.

4. Monitoring dan Evaluasi kegiatan

Penyuluhan dan pelatihan dilaksanakan perumahan AMPTA Permai, Wedomartani, Sleman, Yogyakarta pada bulan Januari 2021 sebanyak 30 peserta dan evaluasi dilakukan oleh pengurus dasawisma terhadap keberhasilan peningkatan pengetahuan terhadap pengolahan makanan bergizi dan pembuatan hand sanitizer ramah lingkungan untuk keluarga dalam mencegah penularan covid19 dengan media whatapp grup dasawisma Sukun.

\section{HASIL DAN PEMBAHASAN}

Pemberdayaan masyarakat berupa punyuluhan dan pelatihan menyediakan makanan bergizi peningkat sistem imun dan pembuatan hand sanitizer ramah lingkungan di dasawisma Sukun sangat membantu masyarakat dalam menambah pemahaman tentang bagaimana mencegah penyebaran covid19 sementara masih banyak masyarakat belum mendapatkan vaksin.

Ibu ibu dasawisma sangat antusias terhadap penyuluhan yang didapatkan, beberapa ibu baru menyadari bahwa bahan makanan sederhana dapat diolah menjadi makanan sehat, bergizi peningkat imun tubuh. Cara pengolahan bahan makanan yang tepat akan meningkatkan cita rasa dan mempertahankan kandungan bergizinya.

Pengabdian masyarakat yang dilakukan berjalan dengan baik, beberapa kegiatan terselenggara sesuai rencana. (1) Penyuluhan tentang bahan makanan yang mengandung zat peningkat sistem imun dengan metode paparan mengunakan media giant screen dan dilengkapi leaflet sangat mengesankan ibu ibu dasawisma Sukun, hal ini dibuktikan dengan antusias memperhatikan materi dan banyaknya pertanyaan terkait materi yang dipaparkan. Angota juga memahami bahwa tidak hanya bahan makanan mengandung protein, vitamin dan mineral yang dapat meningkatkan sistem imun, tetapi istirahat yang cukup dan olah raga teratur juga meningkatkan imun. Kegiatan penyuluhan terlihat pada gambar1.

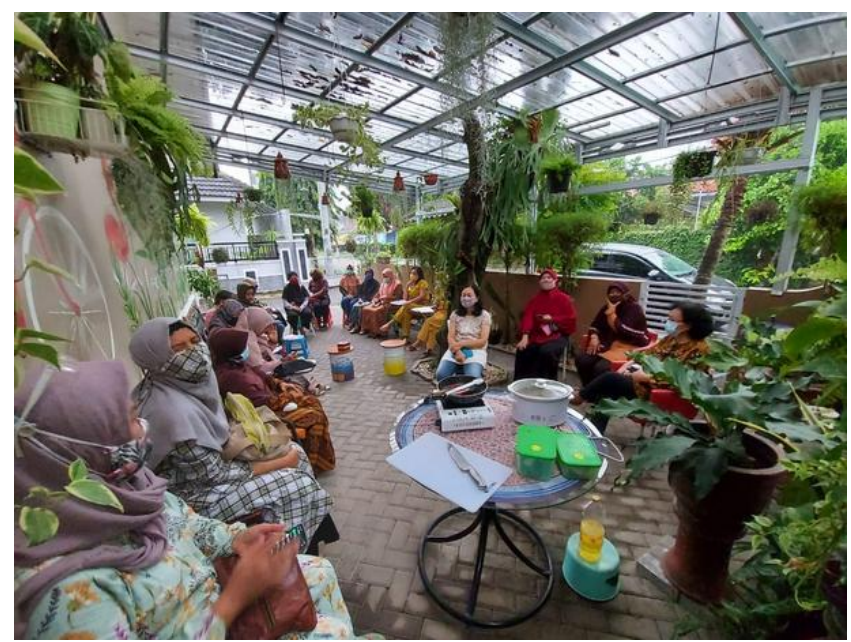

Gambar 1. Penyuluhan pemilihan makanan bergizi penigkat sistem imun 
(2) Pelatihan memasak diawali dengan mencuci semua bahan dengan sabun cair dan air mengalir karena dibeli dari pasar yang sangat tinggi potensi penyebaran covid19, kemudian perlakuan terhadap bumbu seperti bawang putih sebagai antioksidan tidak perlu di cincang hingga lembut sebelum dimasaak karena dapat mengurangi kandungan antioksidan didalamnya. Jika akan menambahkan sayur hijau misal daun bawang, seledri hendaknya dicampur diakhir dan sedapat mungkin dingkat sebelum warna layu. Pengolahan daun hijau disarankan tidak sampai layu karena pemanasan tinggi mengakibatkan kehilangan vitamin $\mathrm{C}$ dan antioksidannya. Daging ayam kampung merupakan sumber protein tinggi tetapi jika pengolahannya tidak tepat seperti memasaknya dengan pemanasan tinggi (dipresto) kemungkinan kandungan protein akan hilang. Ibu ibu dasawisma Sukun tertarik untuk menggunakan slow cooker sebagai alat pengolah bahan mengandung protein yang aman dan berencana untuk membeli secara kolektif. Pelatihan mengolah makanan bergizi terlihat pada gambar 2

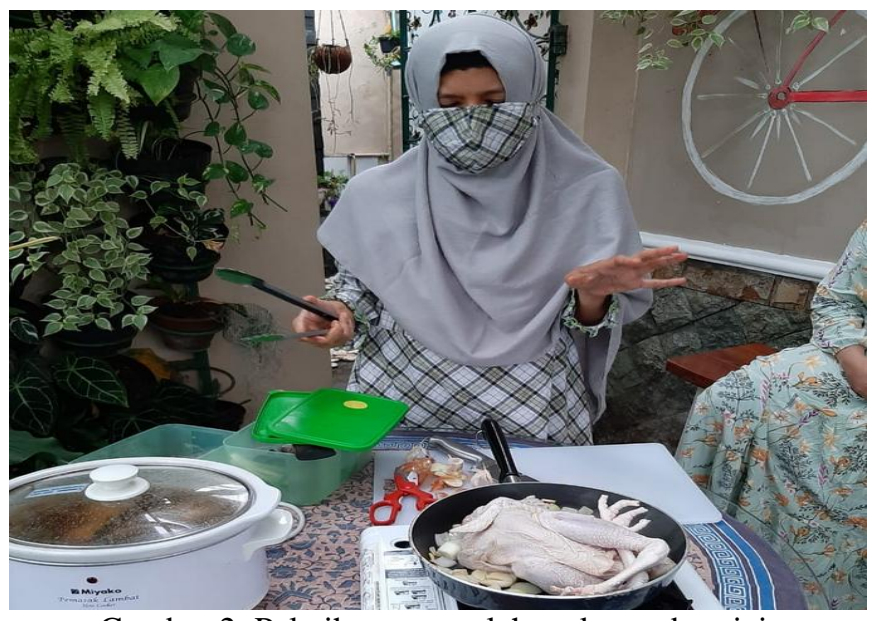

Gambar 2. Pelatihan mengolah makanan bergizi

Penyimpanan masakan panas hendaknya tidak dalam wadah plastik, jika harus masuk wadah plastik hendaknya ditunggu dingin (tidak panas) agar makanan tidak terkontaminasi bahan plastik. Penyimpanan makanan dingin dalam wadah plastik terlihat pada gambar 3 .

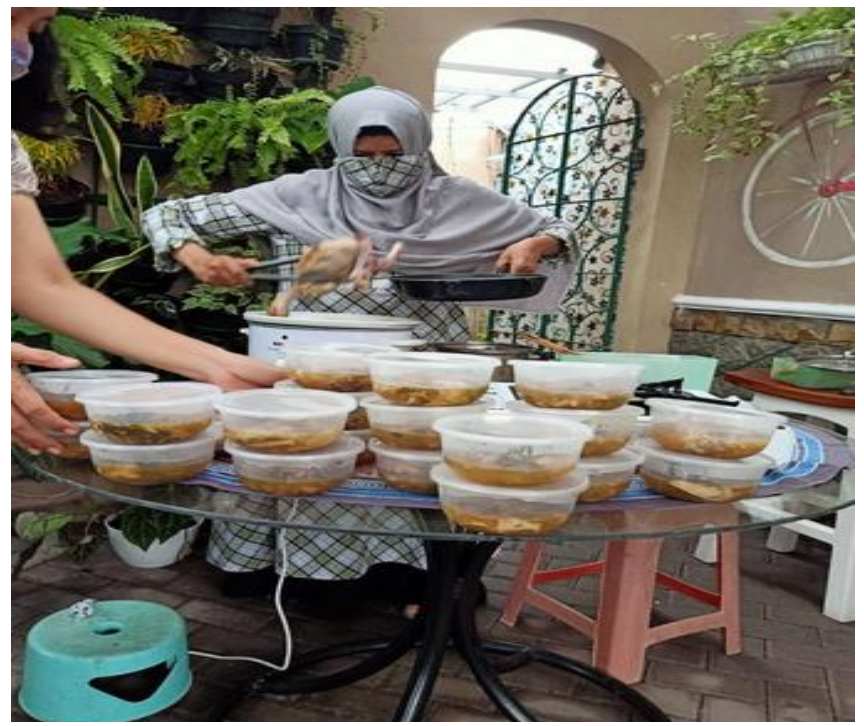

Gambar 3. Penyimpanan makanan dingin dalam wadah plastic 
Makanan pendamping seperti buah berwarna juga disarankan karena banyak mengandung banyak vitamin A, C, mineral, serat dan antioksidan [13]. Buah papaya, jeruk, mangga mudah didapat dan harganya terjangkau.

(3) Pembuatan hand sanitizer berbahan daun sirih yang di steam bertujuan agar kandungan disinfektan tidak rusak sangat menarik perhatian ibu ibu dasawisma Sukun untuk berkreasi membuat handsinitizer berbahan dasar lainnya seperi steam daun salam, daun seledri dan kemangi. Pembuatan hand sanitizer dipraktekkan secara cepat dengan hasil yang memuaskan.

(4) Evaluasi dan monitoring melalui whatapp grup dilakukan oleh pengurus dasawisma Sukun setelah pelaksanaan pengabdian masyarakat ini. Pemahaman masyarakat tentang kandungan gizi bahan makanan untuk meningkatkan system imun meningkat terbukti dengan banyak anggota yang kreatif menggunakan slow cooker untuk memasak ikan dan daging dengan rasa yang lezat tetapi kandungan protein tidak rusak karena pemanasan hanya $60^{\circ} \mathrm{C}$ dalam waktu $10 \mathrm{jam}$. Keretampilan membuat hand sanitizer berbahan herbal berkembang tidak hanya kandungan antiseptik dan aroma yang diperhatikan tetapi banyak anggota berinovasi menambahkan bunga telang sebagai pewarna alami pada hand sanitizer yang dibuatnya.

\section{KESIMPULAN}

Pengabdian masyarakat dilakukan kepada ibu ibu dasawisma Sukun di perumahan Ampta permai, Wedomartani, Sleman, Yogyakarta di hadiri oleh 30 peserta dengan tujuan untuk meningkatkan pemahaman masyarakat tentang pemilihan dan pengolahan bahan makanan yang dapat meningkatkan imun kemudian dilanjutkan dengan pelatihan mengolah bahan makanan menjadi makanan bergizi tanpa merusak kandungannya dan membuat handsinitizer berbahan alam yang ramah lingkungan berhasil.

\section{DAFTAR PUSTAKA}

[1] CDC, "Interim Clinical Guidance for Management of Patients with Confirmed Coronavirus Disease (COVID-19 )," Centers for Disease Control and Prevention, 2020.

[2] Fakultas Farmasi Universitas Gadjah, "Perlunya Peningkatan Sistem Imun pada Pandemi COVID-19," Website FF UGM, 2020. [Online]. Available: https://farmasi.ugm.ac.id/id/perlunya-peningkatan-sistem-imun-padapandemi-covid-19/. [Accessed: 02-Mar-2021].

[3] D. I. Angraini and P. R. Ayu, "The Relationship Between Nutritional Status and Immunonutrition Intake with Immunity Status," JUKE, vol. 4, no. 8, pp. 158-165, 2015.

[4] K. Yuliawati and S. N. Djannah, "Bagaimana pengetahuan, sikap dan perilaku masyarakat tentang konsumsi multivitamin/ supplemen selama pandemi covid-19?,” J. Kesehat. Masy. Khatulistiwa, vol. 7, no. 3, pp. 123-134, 2020 .

[5] Y. Wijasena, "Pentingnya Asupan Gizi Seimbang Di Masa Pandemi Corona," Radio Edukasi, 2020. [Online]. Available: https://radioedukasi.kemdikbud.go.id/read/2421/pentingnya-asupan-gizi-seimbang-di-masa-pandemicorona-.html. [Accessed: 02-Mar-2021].

[6] D. R. A. Muhammad, "Pola Makan Sehat dan Bergizi untuk Meningkatkan Imunitas saat Terserang Covid-19," website Universitas Sebelas Maret, 2020. [Online]. Available: https://uns.ac.id/id/uns-opinion/pola-makan-sehatdan-bergizi-untuk-meningkatkan-imunitas-saat-terserang-covid-19.html. [Accessed: 02-Mar-2021].

[7] L. Amalia, I. Irwan, and F. Hiola, "Analisis Gejala Klinis Dan Peningkatan Kekebalan Tubuh Untuk Mencegah Penyakit Covid-19,” Jambura J. Heal. Sci. Res., vol. 2, no. 2, pp. 71-76, 2020.

[8] A. Buanasita, "PERAN ZAT GIZI UNTUK SISTEM IMUN TUBUH," website UPT Laboratorium Gizi, 2020. [Online]. Available: https://laboratoriumgizi.jatimprov.go.id/peran-zat-gizi-untuk-sistem-imun-tubuh/. [Accessed: 02-Mar-2021].

[9] Siswanto, Budisetyawati, and F. Ernawati, "Peran Beberapa Zat Gizi Mikro Dalam Sistem Imunitas," Gizi Indones., vol. 36, no. 1, pp. 57-64, 2013.

[10] S. Sumarmi, "Kerja Harmoni Zat Gizi dalam Meningkatkan Imunitas Tubuh Terhadap Covid-19: Mini Review," Amerta Nutr., vol. 4, no. 3, p. 250, 2020.

[11] Kementrian Kesehatan Republik Indonesia, "Makanan Bergizi untuk Menjaga Kesehatan Tubuh.” pp. 1-7, 2020.

[12] Liyanan, E. Septianingrum, and B. Kusbiantoro, "Kandungan Unsur Mineral Seng ( Zn ), Bioavailabilitas Dan Biofortifikasinya Dalam Beras,” J. Sungkai, vol. 3, no. 2, pp. 65-73, 2015.

[13] Kementrian Kesehatan Republik Indonesia, "Panduan Gizi Seimbang Pada Masa Covid-19," Kementrian Kesehatan Republik Indonesia. p. 31, 2020.

[14] A. Rauf, Haeria, and D. D. Anas, "Efek Imunostimulan Fraksi Daun Katuk (Sauropus androgynus L.MERR) terhadap aktivitas dan Kapasitas Fagositosis Makrofag Pada Mencit Jantan (mus Musculus)," JF FIK UINAM, vol. 4, no. 1, pp. 9-15, 2016.

[15] C. Fatimah and R. Ardiani, "Pembuatan Hand Sanitizer (Pembersih Tangan Tanpa Air ) Menggunakan Antiseptik Bahan Alami," in Prosiding Seminar Nasional Hasil Pengabdian, 2018, pp. 336-343. 
[16] Y. Angnes, "Pengaruh Karbopol 940 dan Gliserin dalam Formulasi Gel Hand Sanitizer Minyak Atsiri Daun Sirih Hijau (Piper betle Linn) Terhadap Sifat Fisik, Stabilitas Fisik dan Aktivitas Antibakteri Terhadap Escherichia coli.," 2016.

[17] D. R. Puspalani, V. A. Shati, L. M. Listiana, C. D. Damara, and E. C. Gupta, "Membuatan Hand Sanitizer (Pembersih Tangan Tanpa Air ) Menggunakan Daun Sirih Dan Jeruk Nipis,” 2020. 
